\title{
Climatic signal in a radial growth of Canadian and Maximovich poplars in south-western
}

\section{Poland}

\author{
Monika Ziemiańska ${ }^{1 *}\left(\mathbb{0}\right.$, Robert Kalbarczyk ${ }^{1}$, Ji-Ren Chen $^{2}$, Joanna Dobrzańska1(
}

'Wrocław University of Environmental and Life Sciences/ Institute of Landscape Architecture - Division of Engineering and Landscape Protection, 55 Grunwaldzka St. - 50-357 Wrocław - Poland.

${ }^{2}$ Hunan Agricultural University/Horticulture and Landscape College, Changsha - 410128 - Hunan Province, China.

*Corresponding author <monika.ziemianska@upwr.edu.pl>

Edited by: Rafael Rubilar Pons

Received May 9, 2018

Accepted March 27, 2019
ABSTRACT: The main goal set by researchers in this article was to gather knowledge on the structure of the basic biometric features of tree-rings of two species of poplars, belonging to different sections of Aegeiros - Populus xcanadensis and Tacamahaca - Populus maximowiczii, and to define and understand the correlation between weather and annual increment. A supplementary objective of the article was to determine pointer years of species found in individual populations. Our research used the standard methodology applied in dendroclimatology. In the analysis of correlation of the tree species studied, stronger statistically significant relationships were obtained in terms of precipitation-increment compared to temperature-increment. The annual increment in the Canadian poplar was enhanced by wet autumns and winters, especially by the rainfall in Oct and Dec in the previous year, as well as in Apr of this year. The tested Maximovich's poplars tested preferred rainfall during spring going into summer, especially in June of this year. Seven specific pointer years were determined for the Canadian poplar, comprising 4 positive (1987, 2008, 2010, 2012) and 3 negative years (2000, 2011, 2014). For P. maximowiczii, 11 pointer years were determined, i.e. 5 positive years $(1987,1991,1999,2009,2012)$ and 6 negative (1984, 2000, 2002, 2010, 2013, 2015). In the pointer years, monthly sums of atmospheric precipitation and the average monthly air temperatures differed from the multi-year period. In the process of forming the secondary growth of the wood of the studied poplar species, the predominant role was played by atmospheric precipitation.

Keywords: Populus xcanadensis, Populus maximowiczii, dendroclimatology, synchronisation of tree-ring widths, pointer years

\section{Introduction}

Studies on the impact of meteorological elements on the annual growth of trees in Poland started only in the mid-twentieth century, and as of today the majority of indigenous tree species and selected introduced species have already been analysed. In particular, the issues of the influence of thermal-pluvial conditions on the width of annual growth rings of coniferous forest tree species have been of great interest to researchers (Bijak, 2013). The most commonly chosen for long-term absolute chronology studies are long-lived trees with distinctive growth rings, i.e., ring-porous coniferous and deciduous trees. Diffuse-porous deciduous species are characterised by much greater irregularity of growth and the occurrence of growth anomalies under the influence of extreme growth conditions. They are the source of several problems in determining the age of wood (Speer, 2010). Poplar wood is classified as a diffuse-porous type, i.e., in which the vessels are distributed more or less evenly throughout the annual growth ring. As a consequence, the boundaries between early and late growth are unclear and almost imperceptible in the cross-section to the naked eye (Białobok, 1973). To a great extent, the distribution of vessels in the poplar wood depends on the water contained in the substrate. In trees that grow on soil rich in water, the rings are wide and have evenly distributed vessels. However, narrow rings of wood are formed in trees growing under water stress conditions
(Liphschitz and Waisel, 1970). The trees of the Populus genus belong to typical heliophilic species. Light conditions are of great importance to them in the process of photosynthesis, and, more precisely, its intensity which increases in direct proportion to the intensity of light (Dickmann et al., 2001). In current studies of trees of the genus Populus, researchers mostly focus on using them as biomass, which is a source of renewable energy (Moreno-Cortés et al., 2017; Aylott et al., 2008), on using their wood for construction and industry purposes (Kretschmann et al., 1999), and on pulp for the pulp and paper industry (Przybysz and Przybysz, 2013), as well as its application in the pharmaceutical industry (Belkhodja et al., 2016). Many studies focus on the efficiency of poplar cultivation as related to different lengths of production cycles (Pereira et al., 2016; Lamerre et al., 2015; MorenoCortés et al., 2017). Unfortunately, knowledge about the correlation between weather and the annual growth of poplar wood, documented by research, is very scarce. In this study, an attempt was made to learn about the structure of the basic biometric features of annual growth of secondary xylem of the Populus xcanadensis and Populus maximowiczii species and determine the impact of meteorological elements, i.e. atmospheric precipitation and air temperature on the variability of their annual growth. The specific pointer years appearing in individual populations were also determined. The study used samples from trees that perform windbreak and landscape functions, not samples from trees from forest plantations. 


\section{Materials and Methods}

\section{Research location}

The research material came from three research areas: Wilków near Namysłów (latitude: 510ㅗ' $56^{\prime \prime} \mathrm{N}$, longitude: $17^{\circ} 40^{\prime} 13^{\prime \prime} \mathrm{E}$, altitude: $155 \mathrm{~m}$ ), located in the Opolskie Voivodeship, and from Wrocław (latitude: $51^{\circ} 08^{\prime} 47^{\prime \prime} \mathrm{N}$, longitude: $17^{\circ} 04^{\prime} 17^{\prime \prime} \mathrm{E}$, altitude: $116 \mathrm{~m}$ ) and Kwietno (latitude: $51^{\circ} 09^{\prime} 28^{\prime \prime} \mathrm{N}$, longitude: $16^{\circ} 28^{\prime} 34^{\prime \prime}$ E, altitude: $142 \mathrm{~m}$ ) in the Lower Silesian Voivodeship in Poland (Figure 1).

\section{Annual xylem growth - preparation of material} for testing and measurement method

The study was performed on wood discs cut from selected trunks of dominant units and on samples taken using the Pressler increment borer, in accordance with the strategy defined for dendroclimatological research. All samples were taken from the same height, i.e. $1.3 \mathrm{~m}$ above the ground. In total, 76 slices of wood and 26 core bore samples were obtained in the form of rolls with a diameter of approx. $5 \mathrm{~mm}$ (Table 1).

The necessary permits were obtained for sampling, including cutting down trees. Before sampling, the circumferences of tree trunks in $(\mathrm{cm})$ were measured using a measuring tape at a height of $1.3 \mathrm{~m}$. The discs were dried, cut with a gas saw, and their surface was planed with an electric jack plane. Bore samples collected with the use of the Pressler borer were glued to the wooden slats, then their surface was polished with a belt sander and gently cut off.

\section{Annual xylem growth - measurement}

The width of the annual rings was measured using LINTAB ${ }^{\mathrm{TM}} 6$ with an accuracy of $0.01 \mathrm{~mm}$, applying a water filter to increase the contrast between the early and latewood layer (Cedro, 2016). When measuring the width of the annual rings, the incomplete growth of the sampling year was deliberately omitted, as at the time when the field work continued, the cambium activity had not yet finished. The width of the annual growth in the paths selected for measurement paths was measured on the bark-core section with several repetitions. The following codes were created as a result of measuring individual sequences of the annual rings' width: $\mathrm{N}_{\mathrm{W}}$ - Wilków, $\mathrm{W}_{\mathrm{S}}$ - Wrocław, $\mathrm{W}_{\mathrm{K}}$ - Kwietno.

\section{Synchronisation of growth sequences, accepted criteria}

All measured series of annual poplar increments were synchronised. While assessing the quality of the dating of the tested individual sequences, the Gleichläufigkeit coefficient of convergence $(\mathrm{glk}$, $\%)$ was calculated to assess the degree of similarity

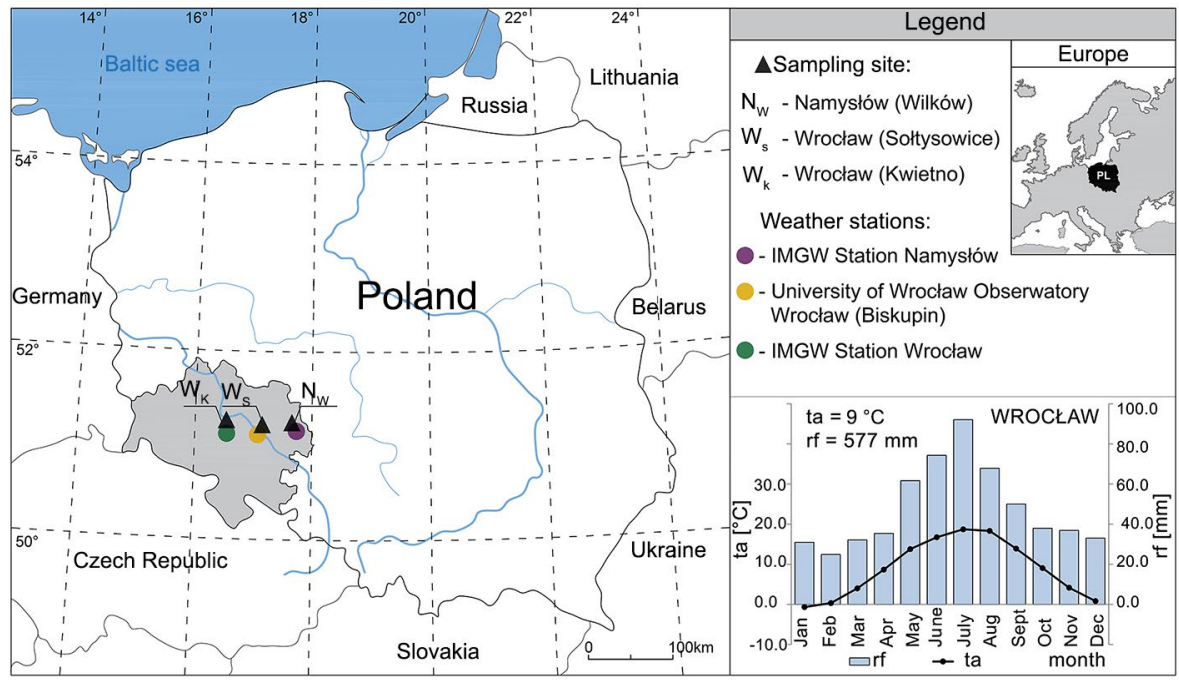

Figure 1 - Area of study in the south-west of Poland and a climograph for Wrocław, 1971-2015.

Table 1 - Basic statistical characteristics of the research material.

\begin{tabular}{|c|c|c|c|c|}
\hline \multirow{2}{*}{$\begin{array}{l}\text { Location / } \\
\text { sequence code }\end{array}$} & \multirow{2}{*}{ Species } & \multicolumn{2}{|c|}{ Number of discs /bore samples } & \multirow{2}{*}{ Area and type of land from which samples were taken } \\
\hline & & collected /(analyzed) & rejected * & \\
\hline Wilków/ $\mathrm{N}_{w}$ & Populus xcanadensis & $55 /(39)$ & 16 & 5.45 hectare, agricultural land \\
\hline Wrocław/W & Populus xcanadensis & $21 /(14)$ & 7 & 2.50 hectare, land currently under development (formerly agricultural) \\
\hline Kwietno/W & Populus maximowiczii & $26 /(26)$ & 0 & $>10.00$ hectare, agricultural land \\
\hline sum: & & $102 /(79)$ & 23 & - \\
\hline
\end{tabular}

*Unsynchronised or damaged during the initial preparatory work. 
in the course of compared growth curves (Kaennell and Schweingruber, 1995). The accuracy of the measurements of annual rings was also assessed by using the graphical compatibility of dendrograms and $t$-test values according to Bailie-Pichler (tvbp) and Hollstein (tvh) (Baillie and Pilcher, 1973; Cook and Kairiukstis, 1990; Rinn, 2012). Studies in the literature have shown that the value of the Hollstein $t$-test should be above 3.5 when $\alpha=0.001$. Using the TSAP-Win software program, the study also determined the crossdating index (cdi), which is an indicator that takes into account the values of the $t$-tvbp and $t$-tvh tests, as well as glk. The cdi minimum threshold value mentioned in the literature is $>20$ at $\alpha=0.001$ (Rinn, 2012). For the series of annual increments, the value of the crosscorrelation was also determined (cc, \%) (Rinn, 2012). The Cofecha software program (Grissino-Mayer, 2001) was also used to assess the quality of the dated sequences, which tested each individual sequence in relation to the mean of all the tested sequences and compared the values of r-Pearson correlation coefficients. In dendrochronology, the value of the Pearson correlation coefficient $(0.328)$ has been considered to be the critical value of this parameter (Holmes, 1983; Holmes, 1994). Individual sequences, $N_{\mathrm{W}^{\prime}} \mathrm{W}_{\mathrm{S}} \mathrm{i}_{\mathrm{K}^{\prime}}$ were also described by means of medium sensitivity $\left(\overline{\mathrm{x}}_{\mathrm{w}} \mathrm{mm}\right)$, which defines the degree of differentiation between successive values in the time data series (Fritts, 1976; Ladányi and Blanka, 2015).

Due to the cambial age of annual increments of trees selected for research, extensive synchronisation criteria were adopted, i.e. obtaining internal consistency and, consequently, the reliability of the chronologies being developed. As a result, by ending the synchronisation phase of the growth curves, a series of those less than 30 years old was rejected, and it significantly influenced the above-described synchronisation parameters. The highest percentage of samples, $33 \%$, in the form of discs were rejected in the group of Canadian poplars, in sequences coded $\mathrm{W}_{\mathrm{S}}$. In bore samples from the Maximovich poplars, the sequences with the $\mathrm{W}_{\mathrm{K}}$ code were synchronised in their entirety, without rejecting any bore samples taken with the increment borer (Table 1).

\section{Meteorological conditions}

The meteorological variables used in the study came from meteorological stations closest to the research area. They were acquired from the Institute of Meteorology and Water Management - National Research Institute (IMGW-PIB) for Wrocław, operating within the national atmosphere monitoring network, and from the Meteorological Observatory of the Department of Climatology and Atmosphere Protection of the University of Wrocław (OMZKiOA UW). In dendroclimatological analyses, mean monthly sums of precipitation $(\mathrm{rf}, \mathrm{mm})$ and average monthly values of air temperature were used $\left(\mathrm{ta}^{\circ}{ }^{\circ} \mathrm{C}\right)$.

\section{Characteristics of chronologies and their} dependence on meteorological conditions

Chronologies: raw, standard and residual were described by means of basic statistical characteristics, including the arithmetic mean $(\overline{\mathrm{x}}, \mathrm{mm})$, standard deviation $(\mathrm{sd}, \mathrm{mm})$, minimum (Min, $\mathrm{mm}$ ) and maximum values (Max, $\mathrm{mm})$, as well as the coefficient of variation $(\mathrm{V}, \%)$. In addition, Pearson's correlation coefficient for the linear trend $(\mathrm{rt})$ and the autocorrelation coefficient $\mathrm{I}^{\circ}$ (rp) were calculated for the chronologies. The creation of chronologies, as well as the determination of individual characteristics, was made using the TSAP-Win software (Time Series Analysis Program) and the Cofecha, Arstan and Statistica 12.5 programs. The ARSTAN software program was used to determine the expressed population signal (EPS), a measure of the similarity between a given tree-ring chronology and a hypothetical chronology that had been infinitely replicated from the individual radii included for a specific common time interval (Wigley et al., 1984). Coherence in the series within a chronology was assessed using the inter-series correlation (rbar) in the detrended tree-ring series.

The influence of meteorological conditions on the increments of the studied poplars was determined by correlation analysis combining the dependent variable (the width of the annual growth rings in the form of residual chronology) with independent variables, i.e. with pluvial and thermal conditions in the growth year of the tree, i.e. in the months of the current year (from Jan to Sept - 1-9), as well as the year preceding the formation of annual rings (from Sept to Dec - 9p-12p), as well as in the combinations of selected months and seasons. The correlation analysis was performed for the common period of all chronologies, i.e. 1984-2014. When determining the species pointer years, one-way changes were assumed in $>90 \%$ of the tested annual growth sequences. Positive pointer years and negative pointer years, i.e. years in which trees developed particularly wide and particularly narrow annual growth rings, were interpreted by assessing deviations from the average long-term monthly values of precipitation totals $(\mathrm{rf}, \mathrm{mm})$ and average monthly air temperature $\left(\mathrm{ta},{ }^{\circ} \mathrm{C}\right)$, calculated for specific pointer years. The relatively strict compliance criterion of $>90 \%$ reduced the number of cases analysed.

\section{Results}

\section{Assessment of the quality of individual sequences}

The highest degree of similarity of the course of the compared growth curves was demonstrated by the sequence of the Canadian poplar with the $\mathrm{W}_{\mathrm{S}}$ code, which was confirmed by a glk indicator that was approx. $85 \%$ (Table 2). On all surfaces tested, the sequences showed higher than required (i.e. $>0.65 \%$ ) convergence coefficient values. In the case of the poplars analysed, the highest value of the $t$ test according to Bailie-Pichler (tvbp) and Hollstein (tvh) was obtained for the Canadian 
poplar sequence with the $\mathrm{N}_{\mathrm{w}}$ code (which was 6.9) and for the $\mathrm{W}_{\mathrm{s}}$ code - 6.4. A slightly lower value was obtained for the Maximovich poplars with $\mathrm{W}_{\mathrm{K}}$ code - 5.4.

Satisfactory results for the growth curves measured were also obtained using the cross-dating index (cdi), as cdi for $\mathrm{N}_{\mathrm{W}}$ was 52.0, while for $\mathrm{W}_{\mathrm{S}}$ it was -47.8 and for $\mathrm{W}_{\mathrm{K}}$ - 47.5. The cross-correlation values (cc, \%) ranged from approx. 66 to as much as $85 \%$; and the highest was determined for $\mathrm{W}_{\mathrm{K}}$. In turn, Pearson correlation coefficient values were similar for all poplar growth sequences, ranging from 0.66 for $\mathrm{N}_{\mathrm{W}}$ to 0.68 for $\mathrm{W}_{\mathrm{K}}$.

\section{Statistical characteristics of annual increments}

The average age of a Canadian poplar sequence with the $\mathrm{N}_{\mathrm{W}}$ code accepted for analysis was 42 years, with the $\mathrm{W}_{\mathrm{S}}$ code it was 32 years, and the for the Maximovich poplar sequence 31 years (Table 3). The mean annual ring width of Populus canadensis was $6.63 \mathrm{~mm}$ for the $\mathrm{N}_{\mathrm{w}}$ sequence and $8.30 \mathrm{~mm}$ for the $\mathrm{W}_{\mathrm{S}}$ sequence. The mean annual ring width determined for Populus maximowiczii was $7.38 \mathrm{~mm}$. The widest increment was measured in the sequences with the $\mathrm{W}_{\mathrm{s}}$ code, and it was as much as 29.71

Table 2 - Statistical evaluation of the dating quality relating to the tested individual sequences $N_{W}, W_{S}, W_{K}$.

\begin{tabular}{|c|c|c|c|c|}
\hline \multirow{3}{*}{ Synchronisation parameter } & \multirow{3}{*}{ Software } & $\begin{array}{r}\text { Pop } \\
\text { canad }\end{array}$ & $\begin{array}{l}\text { ulus } \\
\text { densis }\end{array}$ & $\begin{array}{c}\text { Populus } \\
\text { maximowiczii }\end{array}$ \\
\hline & & \multicolumn{3}{|c|}{ Sequence code } \\
\hline & & $N_{w}$ & $W_{s}$ & $W_{k}$ \\
\hline Gleichläufigkeit, (\%) (g|k) & \multirow{5}{*}{ TSAP-Win } & 78 & 85 & 80 \\
\hline t-value Bailie-Pichler (tvbp) & & 6.2 & 4.5 & 5.8 \\
\hline t-value Hollstein (tvh) & & 6.9 & 6.4 & 5.4 \\
\hline Cross-Date Index (cdi) & & 52.0 & 47.8 & 47.5 \\
\hline Cross-correlation, (\%) (cc) & & 66 & 78 & 85 \\
\hline r-Pearson correlation coefficient & COFECHA & 0.66 & 0.67 & 0.68 \\
\hline
\end{tabular}

$\mathrm{mm}$. The narrowest annual ring was determined for $\mathrm{N}_{\mathrm{w}^{\prime}}$ and it was $0.70 \mathrm{~mm}$. The annual growths of Maximovich poplar wood were characterised by the highest coefficient of variation $(\mathrm{V}, \%)$, which was $66 \%$, and a slightly lower value of the coefficient was obtained for the Canadian poplar $\left(\mathrm{W}_{\mathrm{S}}\right.$ sequence $-50 \%$ and $\mathrm{N}_{\mathrm{w}}-46 \%$ ) (Table 3). The average sensitivity $\left(\overline{\mathrm{x}}_{\mathrm{w}}\right)$ that determines tree susceptibility to environmental stresses for Populus canadensis was 0.26 , and for Populus maximowiczii 0.37.

Larger trunk circumferences were obtained for the Canadian poplar trees both in Wilków and Wrocław (Table 3). The average circumference of the trunk of the Maximovich poplar was only $156 \mathrm{~cm}$ and was 36 $\mathrm{cm}$ smaller than the average circumference of the Canadian poplars from the Wilkow research area and 11 $\mathrm{cm}$ smaller than the trees from Wrocław. The maximum circumference of the trunk $(260 \mathrm{~cm})$ was measured for the Canadian poplar tree; the smallest circumference $(108 \mathrm{~cm})$ was for the Maximovich poplar tree. On all research surfaces, the trees grew in similar spacing, in a row configuration, performing the same windbreak and landscape functions.

\section{Site chronologies}

All raw chronologies of the studied poplars were created by averaging individual growth curves. The first of Populus canadensis chronology with an NWP code was 44 years old and lasted from 1971 to 2014; the second chronology of the same species with a WSP code was 34 years old and lasted from 1984 to 2015. The Populus maximowiczii chronology with a WKP code was the shortest at 32 years old and lasted only from 1984 to 2015 (Figure 2A). The average width of the annual rings in all raw chronologies produced in the mentioned multi-year periods was similar and was, respectively, $6.38 \mathrm{~mm}$ for the NWP chronology, $7.62 \mathrm{~mm}$ for the WSP and 7.23 for the WKP (Table 4). The smallest and largest width of the annual increment was recorded in the raw chronology of the Maximovich poplar; its lowest value

Table 3 - Statistical characteristics of annual increments of individual sequences and trunk circumferences of the studied trees.

\begin{tabular}{|c|c|c|c|}
\hline \multirow{4}{*}{ Characteristics } & \multicolumn{3}{|c|}{ Species name } \\
\hline & \multicolumn{2}{|c|}{ Populus canadensis } & Populus maximowiczii \\
\hline & \multicolumn{3}{|c|}{ Sequence code } \\
\hline & $\mathrm{N}_{\mathrm{w}}$ & $W_{S}$ & $W_{k}$ \\
\hline Cambial age (number of years) & $44-38$ & $34-30$ & $32-30$ \\
\hline $\bar{x} \pm s d(m m)$ & $6.63 \pm 3.05$ & $8.30 \pm 5.72$ & $7.38 \pm 4.78$ \\
\hline Min $(\mathrm{mm}) /$ year & $0.70 / 2005$ & $1.39 / 2005$ & $0.79 / 2011$ \\
\hline $\operatorname{Max}(\mathrm{mm}) /$ year & $18.58 / 1980$ & $29.71 / 1986$ & $25.48 / 1990$ \\
\hline V (\%) & 46 & 50 & 66 \\
\hline$\overline{\mathrm{x}}_{\mathrm{w}}$ & 0.26 & 0.26 & 0.37 \\
\hline Tc, $\bar{x} \pm s d(\mathrm{~cm})$ & $192.0 \pm 34$ & $167 \pm 30$ & $156 \pm 21$ \\
\hline Tc, Min (cm) & 113 & 142 & 108 \\
\hline Tc, Max $(\mathrm{cm})$ & 260 & 249 & 193 \\
\hline Tc, V (\%) & 18 & 18 & 14 \\
\hline
\end{tabular}

Explanatory note: $\bar{x} \pm s d=$ mean \pm standard deviation $(\mathrm{mm}) ; \operatorname{Min}=$ the minimum value $(\mathrm{mm}) ;$ Max $=$ the maximum value $(\mathrm{mm}) ; \mathrm{V}=$ coefficient of variation (\%); $\overline{\mathrm{x}}_{\mathrm{w}}=$ medium sensitivity; Tc $=$ trunk circumference at $\mathrm{h}=1.3 \mathrm{~m}(\mathrm{~cm})$. 
Table 4 - Statistical indicators describing raw, standard and residual chronologies of NWP, WSP, WKP.

\begin{tabular}{|c|c|c|c|c|c|c|c|c|c|}
\hline \multirow{4}{*}{ Indicators } & \multicolumn{9}{|c|}{ Chronologies - codes } \\
\hline & \multicolumn{3}{|c|}{ Raw-data } & \multicolumn{3}{|c|}{ Standard } & \multicolumn{3}{|c|}{ Residual } \\
\hline & \multicolumn{2}{|c|}{ P. canadensis } & \multirow{2}{*}{$\frac{\text { P. maximowiczii }}{\text { WKP }}$} & \multicolumn{2}{|c|}{ P. canadensis } & \multirow{2}{*}{$\frac{\text { P. maximowiczii }}{\text { WKP }}$} & \multicolumn{2}{|c|}{ P. canadensis } & \multirow{2}{*}{$\frac{\text { P. maximowiczii }}{\text { WKP }}$} \\
\hline & NWP & WSP & & NWP & WSP & & NWP & WSP & \\
\hline Time interval & $1971-2014$ & $1981-2014$ & $1984-2015$ & $1971-2014$ & $1981-2014$ & $1984-2015$ & $1971-2014$ & $1981-2014$ & $1984-2015$ \\
\hline $\bar{x} \pm s d(m m)$ & $6.38 \pm 1.86$ & $7.62 \pm 3.11$ & $7.23 \pm 4.12$ & $0.99 \pm 0.22$ & $1.01 \pm 0.27$ & $1.04 \pm 0.40$ & $0.99 \pm 0.19$ & $0.99 \pm 0.23$ & $1.00 \pm 0.39$ \\
\hline $\operatorname{Min}(\mathrm{mm})$ & 3.75 & 3.44 & 2.22 & 0.62 & 0.45 & 0.40 & 0.64 & 0.37 & 0.52 \\
\hline $\operatorname{Max}(\mathrm{mm})$ & 10.89 & 14.54 & 14.70 & 1.64 & 1.74 & 2.43 & 1.47 & 1.64 & 1.81 \\
\hline V (\%) & 25 & 41 & 57 & 23 & 27 & 38 & 19 & 23 & 39 \\
\hline $\mathrm{rt}$ & $-0.37^{1}$ & $-0.62^{1}$ & $-0.58^{1}$ & $-0.01 \mathrm{~ns}$ & $0.05 \mathrm{~ns}$ & $-0.18 \mathrm{~ns}$ & $-0.08 \mathrm{~ns}$ & $0.22 \mathrm{~ns}$ & $-0.15 n s$ \\
\hline $\mathrm{rp}$ & 0.58 & 0.75 & 0.85 & 0.48 & 0.39 & $0.22 \mathrm{~ns}$ & $-0.22 n s$ & $0.05 \mathrm{~ns}$ & $0.19 \mathrm{~ns}$ \\
\hline
\end{tabular}

Explanatory note: NWP, WSP, WKP = codes of chronology, $\bar{x} \pm \mathrm{sd}=$ mean \pm standard deviation $(\mathrm{mm}) ;$ Min $=$ the minimum value $(\mathrm{mm})$; Max $=$ the maximum value $(\mathrm{mm}) ; \mathrm{V}=$ coefficient of variation (\%); $\overline{\mathrm{x}}_{\mathrm{w}}=$ medium sensitivity; $\mathrm{rt}=$ correlation coefficient of linear trend; ${ }^{1}$ significant at $p<0.05, r p=$ coefficient of autocorrelation ${ }^{\circ}$ at least at $\alpha \leq 0.05 ; \mathrm{ns}=$ statistically insignificant at least at $\alpha \leq 0.1$.

was $2.22 \mathrm{~mm}$, and the highest $-14.70 \mathrm{~mm}$. Whatsmore, in the case of this chronology, the coefficient of variation was the highest and was as much as $57 \%$.

The time distributions of the annual growths of the poplars tested were characterised by a negative, statistically significant age trend, which indicates that each year the secondary increments of the wood were smaller (for NWP rt $=-0.37$, for WSP $\mathrm{rt}=-0.62$, for WKP rt $=-0.58 ; \alpha \leq 0.01$ ) (Table 4). The structure of the annual increments of wood of the trees examined was also characterised by a positive, statistically significant coefficient of first-degree autocorrelation (for NWP rp $=0.58$, for WSP rp $=0.75$, for WKP rp $=0.85 ; \alpha \leq$ $0.05)$. In connection with the above, the time series of annual increments of $P$. canadensis and $P$. maximowiczii were transformed first into standard chronologies, thus eliminating the linear trend (for NWP rt $=-0.01$, for WSP rt $=0.05$, for WKP rt $=-0.18 ; \alpha \leq 0.05)$, then into a residual chronology, excluding first degree autocorrelation (for NWP rp $=-0.22$, for WSP rp $=0.05$, for WKP $\mathrm{rp}=0.19$; at $\alpha \leq 0.05)$. The chronologies presented in the study should be regarded as representative, since the coefficients of the expressed population signal (EPS) reached high values for all chronologies (EPS for NWP $=0.96$; EPS for WSP $=0.94$; EPS for WKP $=0.95)$. Rbar values for individual chronologies achieved the following values: for NWP $=0.47$; for $\mathrm{WSP}$ and $\mathrm{WKP}=0.55$.

\section{Dendroclimatological analysis}

Strong statistical relationships were observed in the analysis of correlation in the precipitation-increment relation for the Canadian poplar. The study found only positive values for the correlation coefficient, which reached statistically significant values in Oct and Dec of the year preceding the growth under analysis $(\mathrm{r}=$ 0.39 for Oct and $r=0.50$ for Dec, at $\alpha \leq 0.05)$ and in Apr this year $(r=0.43$ at $\alpha \leq 0.05)$. When considering the impact of rainfall on the course of chronology of poplars in longer periods of 2-3 months, a statistically significant correlation was found at the turn of the year, i.e. the Dec-Jan period ( $\mathrm{r}=0.49$ at $\alpha \leq 0.05)$, and in the

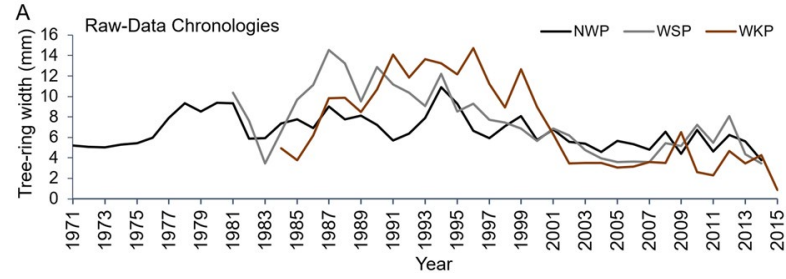

B

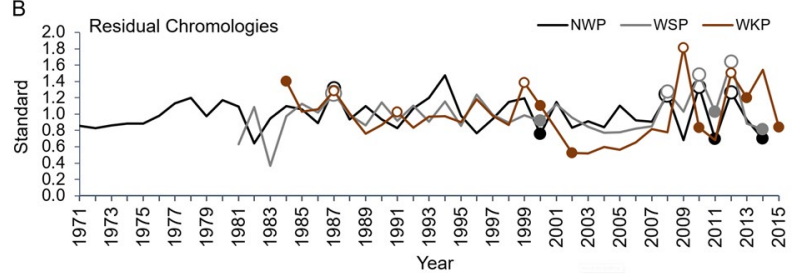

Figure 2 - Summary of the course of raw chronologies a. and residual chronologies $b$. along with an indication of the occurrence of specific pointer years. Black, gray and brown markers are negative pointer years, and markers without filling are positive pointer years

aforementioned seasons of the year, for winter $(\mathrm{r}=0.46$ at $\alpha \leq 0.05)$ (Figure 3.). When assessing the correlation between precipitation and annual growth for Maximovich poplars, statistically significant coefficients for Nov of the year preceding the growth $(\mathrm{r}=-0.48$ at $\alpha \leq 0.05)$ and for June of the current year $(r=0.43$ at $\alpha \leq 0.05)$, and, additionally, for the combination of months MayJune $(\mathrm{r}=0.50$ at $\alpha \leq 0.05)$ and June-July $(\mathrm{r}=0.35$ at $\alpha \leq$ $0.05)$, were observed.

The correlation analysis showed a minor role for air temperature $\left(\mathrm{ta}^{\circ}{ }^{\circ} \mathrm{C}\right)$ in the process of forming the annual increment of $P$. canadensis. A statistically significant value was achieved only in Sept of the current year $(\mathrm{r}$ $=-0.38$ at $\alpha \leq 0.05$ ) for the WSP chronology (Figure 3). Similarly for $P$. maximowiczii, chronology with the WKP code, air temperature played a minor role in the annual ring formation process. All calculated indicators had negative values and were mainly related to one month. Statistically significant values were calculated for June 

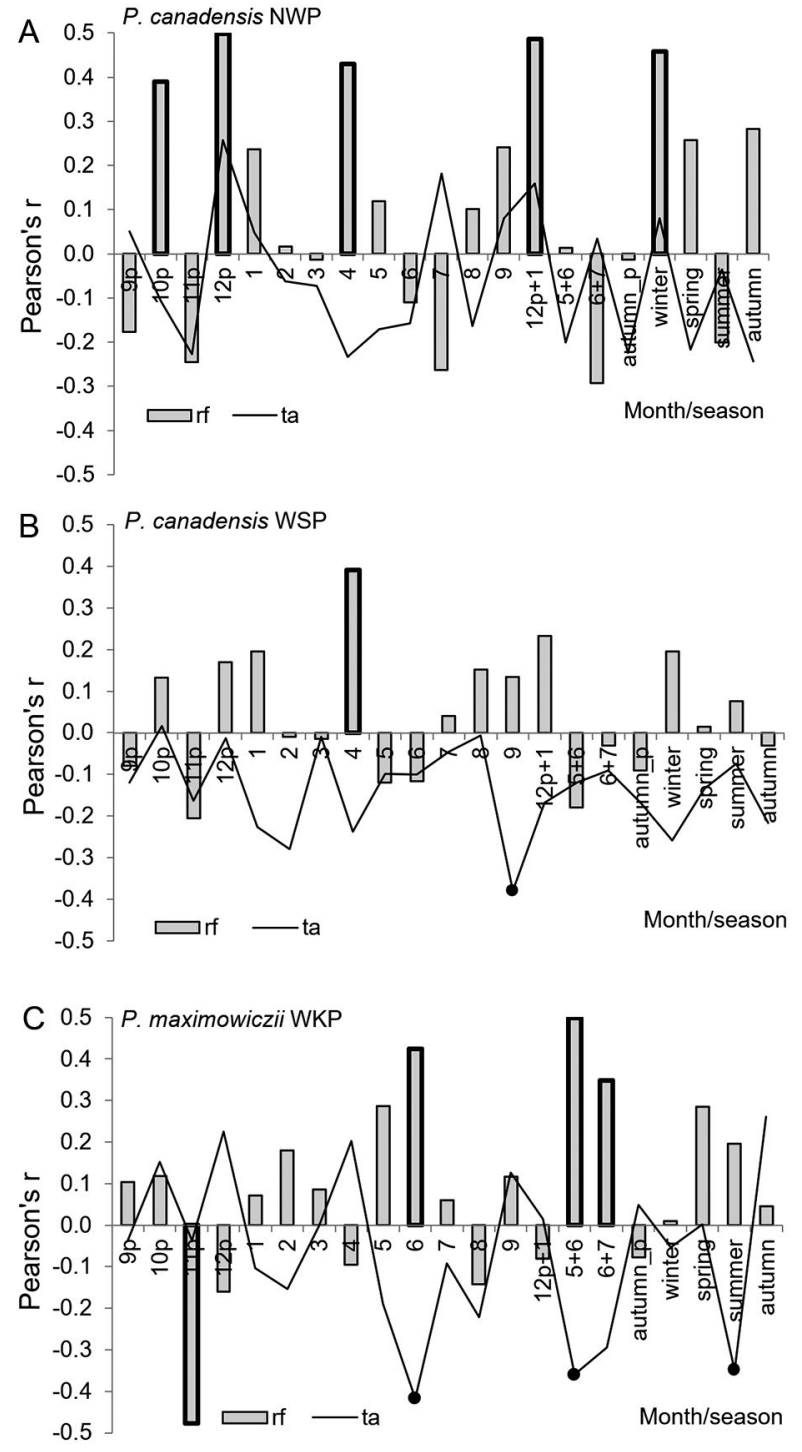

Figure 3 - Results of the correlation analysis of residual chronologies NWP A, WSP B, WKP C and atmospheric precipitation (rf) - columns and air temperatures (ta) - continuous line; statistically significant values at $\alpha=0.05$ are shown in the form of outlined columns and filled black markers. Time range from $9 p$... to 9 , which is from Sept of the year preceding the growth of rings to Sept in the growth year of the tree, $p$ - the year preceding the formation of the rings.

of the current year $(r=-0.41$ at $\alpha \leq 0.05)$ and combinations of months of May-June of the current year $(\mathrm{r}=$ -0.36 at $\alpha \leq 0.05$ ), and in the season under analysis, for the summer $(\mathrm{r}=-0.35$ at $\alpha \leq 0.05)$, as well as this year.

\section{Pointer years}

For two site chronologies of $P$. canadensis of NWP and WSP codes, 7 specific pointer years were calculated, including 4 positive $(1987,2008,2010,2012)$ and 3 negative years $(2000,2011,2014)$ (Figure 2A, B). For the site chronology of $P$. maximowiczii with a WKP code, 11 pointer years were identified, i.e. 5 positive years (1987, 1991, 1999, 2009, 2012) and 6 negative years (1984, $2000,2002,2010,2013,2015)$. In addition, there were 3 "common" pointer years found for all chronologies of both the Canadian poplar and Maximovich poplar, including 2 positive years $(1987,2012)$ and 1 negative year (2000). There was a special year in 2012 , when $100 \%$ of the surveyed trees produced increased growth.

\section{Pluvial-thermal conditions prevailing in the pointer years of $\boldsymbol{P}$. canadensis}

Analysis of weather conditions in the years determined to be specific to $P$. canadensis allowed for linking the occurrence of positive pointer years with higher atmospheric precipitation than in the multi-year period, especially in May and at the turn of the year, i.e. in Dec of the year preceding the increment and Jan of the current year. Significantly higher rainfall was also recorded in Aug and Sept of the current year. The Canadian poplars developed wider growth rings in positive years, when the air temperature was higher than in the multi-year period in Nov and Dec of the year preceding the formation of the growth, as well as June and especially in July of the current year. It was also found that the formation of wider growth rings of Canadian poplar was accompanied by lower temperatures than in the multi-year period, especially from Jan to Mar of the current year and in May (Figure 4). In the monitoring period of development of the Canadian poplar (over 13 months), narrower annual growths of wood formed in negative pointer years could be linked to lower than normal precipitation in as many as 7 months, i.e. June of the current year and Oct of the year preceding the growth, as well as Feb and Apr of the current year. In the negative pointer years, the rainfall was also lower than in the multi-year period for Dec of the year preceding the growth, and in Aug and Sept of the current year (Figure 4). The average monthly air temperatures in the months of the negative pointer years analysed were more often higher than during the multi-year period.

On the basis of the analysis of pluvial and thermal conditions in the pointer years, it was found that the Canadian poplar prefers (then produces wider annual growth rings) temperatures that are colder than the average winter months (Jan, Feb) and higher than normal precipitation in winter (Dec, Jan). A warmer than normal month was also observed in spring around Apr, and rainfall was higher than in the multi-year period at the end of spring, i.e. in May. In summer (June, July) when assessing the rainfall-thermal conditions for the Canadian poplar, less than average atmospheric precipitation was observed at simultaneous higher temperatures than in the multi-year period. The conditions recorded in the last month of summer (Aug) and at the beginning of autumn (Sept), when rainfall is higher than average together with a lower temperature than normal, also favor the formation of wider annual rings. 


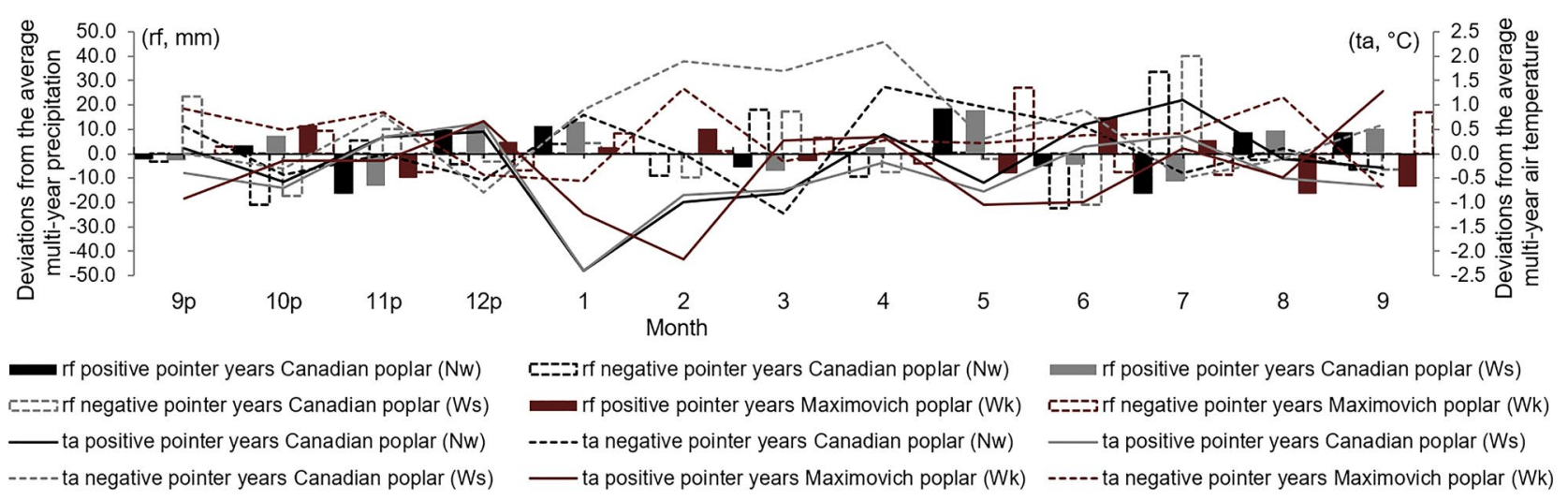

Figure 4 - Deviations from the average multi-year precipitation ( $\mathrm{rf}, \mathrm{mm})$ and air temperature $(\mathrm{ta}, \mathrm{oC})$ totals in the growth year of the tree, i.e. from $9 p$... to 9 (from Sept to Sept) in the positive and negative pointer years; $p$ is the year preceding the growth. Columns mean deviations for (rf), lines - for (ta).

\section{The pluvial-thermal conditions prevailing in the pointer years of $\boldsymbol{P}$. maximowiczii}

In the positive pointer years of Maximovich poplars, there was higher precipitation compared to the multi-year period, especially in June of the current year, Oct in the year preceding the growth, as well as in Feb of the current year. The Maximovich poplar formed wider growth rings in positive years, when the air temperature was higher than in the multi-year period, especially in Sept of the current year and in Dec in the year preceding the growth. In the months considered in the growth year of $P$. maximowiczii, the formation of wider rings was accompanied more often by lower average monthly air temperatures than in the multi-year period. For the 13 months analysed in 8 of them the average monthly air temperature was lower and the deviation from the norm was in the range of $1.3{ }^{\circ} \mathrm{C}$ to $-2.2{ }^{\circ} \mathrm{C}$ (Figure 4). In the time of tree development under consideration, the formation of narrower growths in $P$. maximowiczii was accompanied by higher monthly average temperatures compared to the multiyear period in as many as 9 out of 13 months. Higher temperatures were recorded, especially in Feb and Aug of the current year.

As a result of the analysis of pointer years, it was found on examination that $P$. maximowiczii prefers producing wider annual rings in cooler winter months (Jan, Feb) than in the multi-year period and higher than standard rainfall in all winter months (Dec, Jan, Feb). Preferences were also found, expressed in larger annual growth for warmer than average months in spring (Mar, Apr). The higher growth in May, however, was determined by lower rainfall and lower temperatures compared to the multi-year period. Maximovich poplar produces wider growth rings in the summer months (in June and July) when there is more rainfall and lower air temperatures (in July the average). The analysed thermal-pluvial conditions at the end of the summer (Aug) and the beginning of au- tumn (Sept), responsible for wider growth rings, were varied and meant less rainfall than average, as well as lower in Aug and higher in Sept average monthly air temperatures.

\section{Discussion}

In the study, consistency and similarity in the variability of the time series of annual growths of the Canadian poplars $\left(\mathrm{W}_{\mathrm{N}^{\prime}}, \mathrm{W}_{\mathrm{S}}\right)$ and Maximovich poplars were observed $\left(\mathrm{W}_{\mathrm{K}}\right)$ (Figure 2), and these suggest the influence of environmental factors on the annual growth of the trees examined. The high values of growth sequence synchronisation parameters included in the study (Table 2) (glk, tvp, tvh, cdi, cc and Pearson correlation coefficient) allowed the assumption to be made that the annual growth data sets obtained were well synchronised and can be used in the study of weather-growth correlation (Rinn, 2012; Grissino-Mayer, 2001; Holmes, 1994; Schweingruber, 1988). Annual growths of the species studied were sensitive to weather conditions, which showed statistically significant high values of coefficients in the correlation analysis. In the study of weather-growth correlation, in the case of the two independent variables considered, the factor limiting the process of annual growth formation in both $P$. canadensis and $P$. maximowiczii was atmospheric precipitation. A different situation, where the limiting factor was the air temperature, was observed by the Šenhof team (2016) in studies on fast growing poplar hybrids and aspen poplar hybrids in western and central Latvia. Such a difference in the reaction of trees may be due to a higher total of annual atmospheric precipitation, as well as the greater thickness of the snow cover and the duration of its retention in this part of Latvia (Auce and Škēede, $620 \mathrm{~mm}$ ) than in south-western Poland (Wrocław, $577 \mathrm{~mm}$ ). In the study, statistically significant conformity of the reaction of two chronologies of the Canadian poplar to atmospheric precipitation in Apr under the conditions of south-eastern 
Poland was observed. This can be explained by the large demand of trees for water during the period of entry into the phenological phase of leaves unfolding and during the reactivation of the cambium after the winter rest (Białobok, 1973). The spring demand of poplars for water is also related to the date of the beginning of the growing season, which in the research area begins at the earliest in Poland in mid-Mar (Tomczyk and Szyga-Pluta, 2018). P. canadensis reacted significantly to precipitation in winter, in the period of Dec-Jan and especially in Dec. Precipitation and snow cover in the winter months has an impact on the level of groundwater, which in early spring provides the opportunity to supplement any shortages and start the uptake of nutrients for trees. In addition, poplars tolerate possible high groundwater levels, so that even a large water supply due to winter precipitation is safe for the trees. According to the research carried out in south-western Slovakia by Paganová et al. (2009), the size of the annual growth of poplars is influenced not only by meteorological but also by hydrological elements expressed by the level of groundwater. Statistically significant values were examined, especially during periods of the lowering of the water table. Knowledge of the correlation between weather and the growth of hybrids of the Populus genus growing in various European edaphic and climate conditions is currently very limited. A small amount of published, long-term research in the field of dendroclimatology of trees of the genus Populus has also been mentioned by other researchers such as Trnka et al. (2016), and Šēnhofa et al. (2016) among others. In the study of the climate-growth correlation, the difference in reaction of the Canadian poplar trees between the Wilków and Wrocław sites was observed. The authors assume that a partial difference of the reaction may be the result of the different density of trees during the growth at sites, and the impact of the surroundings (neighborhood) including the vicinity of the road and various soil conditions. The thermal conditions analysed in the growth year of the Canadian poplar tree in negative years can be interpreted as follows: narrower growth rings are due to lower temperatures in Oct and Dec of the year preceding growth and higher average temperatures in Jan and Feb, as well as from Apr to June of the current year. In the time interval analysed (13 months), narrower annual wood growths emerging in negative pointer years $P$. maximowiczii can be related to those lower than in the multi-year period rainfall values, especially in June and July of the current year, and in Nov and Dec of the year preceding growth. The pointer years, both positive and negative, identified in the study have also been demonstrated in other studies in Poland and Europe. The periods of 2000-2002, and 2015 are the years in which deep droughts occurred (Ionita et al., 2017; Spinoni et al., 2015; Zieliński et al., 2009). Thus, in many dendroclimatological studies, these years were defined as negative pointer years, especially 2000 (Ducić et al., 2015; European Commission, 2011; Čejková and Kolář, 2009). Annual growth rings in poplar hybrids in Latvia in 2002 reacted with a decrease in growth (Šēnhofa et al., 2016), as did sessile oaks in Romania (Nechita, 2013) and Serbia (Stajić et al., 2014), as well as P. maksymowiczii in south-western Poland. In the chronology of $P$. maximowiczii, pointer years were recorded, which were also analysed by the team of Bijak et al. (2012) in Quercus robur and Q. rubra research in Central Poland, as well as in research on Fraxinus excelsior and Alnus glutinosa, conducted by Wojtan and Tomusiak (2014), also in Central Poland. The pointer years specified for $P$. canadensis were also described in the research of Cedro (2016) for Sorbus torminalis.

\section{Conclusions}

The results obtained in this research can be used to develop new production and regionalization technologies which can be applied to the cultivation of fast-growing trees under agroforestry meteorological protection together with agrometeorological forecasts, to develop adaptive strategies and mechanisms for expanding the cultivation of fast-growing trees in the context of predicted and identified climate changes. Taking into account the distribution of rainfall and temperature values, it is possible to effectively plan the location of poplar plantations. Knowing the pluvial and thermal preferences of the species studied, one can also try to influence production efficiency in the area of already existing poplar plantations, especially in short production cycles. Selection of all specimens within the surveyed populations and economic species with even, intensive increments and desirable qualitative traits can contribute to the extensive production of wood pulp, and thus reduce the $\mathrm{CO}_{2}$ content in the atmosphere and improve production efficiency.

\section{Authors' Contributions}

Conceptualization: Ziemiańska, M.; Kalbarczyk, R. Data acquisition: Ziemiańska, M.; Dobrzańska, J. Data analysis: Ziemiańska, M.; Kalbarczyk, R.; Chen, J.R. Design of methodology: Ziemiańska, M.; Kalbarczyk, R.; Chen, J.R. Writing and editing: Ziemiańska, M.; Kalbarczyk, R.; Chen, J.R.; Dobrzańska, J.

\section{References}

Aylott, M.J.; Casella, E.; Tubby, I.; Street, N.R.; Smith, P.; Taylor, G. 2008. Yield and spatial supply of bioenergy poplar and willow short-rotation coppice in the UK. The New Phytologist 178: 358-370.

Baillie, M.G.L.; Pichler, J.R. 1973. A simple cross date program for tree-ring research. Tree-Ring Bulletin 33: 7-14.

Belkhodja, H.; Boumediene, M.; Aicha, T.T.; Nazim, Ş. 2016. Chemical composition and DNA damage protective effect of essential oil of Rosmarinus officinalis and Populus alba. International Journal of Phytopharmacology 7:196-201. 
Białobok, S. 1973. Topole Populus L. = Poplar Populus L. Wydawnictwo. PWN, Warsaw, Poland (in Polish).

Bijak, Sz.; Bronisz, A.; Bronisz, K. 2012. Effect of climate conditions on radial increment of pendunculate and red oaks in Rogów. Studia i Materiały CEPL 1: 121-128 (in Polish, with abstract in English).

Bijak, Sz. 2013. Climate signal in the radial growth of selected coniferous species from the Forest Experimental Station in Rogów. Forest Research Papers 74: 101-110.

Cedro, A. 2016. The influence of climatic conditions on the tree-ring width of wild service trees (Sorbus torminalis L.) in Wielkopolska. Forest Research Papers 77: 117-123.

Čejková, A.; Kolář, T. 2009. Extreme radial growth reaction of Norway spruce along an altitudinal gradient in the Šumowa mountains. Geochronometria 33: 41-47.

Cook, E.R.; Kairiukstis, L.A. 1990. Methods of Dendrochronology: Applications in the Environmental Sciences. Kluwer Academic, Dordrecht, Netherlands.

Dickmann, D.I.; Isebrands, J.G.; Blake, T.J.; Kosola K.; Kort, J. 2001. Physiological ecology of poplars. p. 77-106. In: Dickmann, D.I.; Isebrands, J.G.; Eckenwalder, J.E.; Richardson, J., eds. Poplar culture in North America. NRC Research Press, Ottawa, Canada.

Ducić, V.; Ivanović, R.; Mijhajlivić, J.; Gnjato, R.; Trbić, G.; Ćurčić, N.B. 2015. Dendroindication of drought in Rogatica region (Estern Bosnia). Archives of Biological Sciences 67: 201-211.

European Commission. 2011. The Condition of Forests in Europe. Institute of World Forestry, Brussels, Belgium. (Executive Report).

Grissino-Mayer, H.D. 2001. Evaluating cross-dating accuracy: a manual and tutorial for the Cofecha computer program. Tree Ring Research 57: 205-221.

Fritts, H.C. 1976. Tree Rings and Climate. Blackburn Press, Caldwell, NJ, USA.

Holmes, R.J. 1983. Computer-assisted quality control in tree-ring dating and measurement. Tree-Ring Bulletin 43: 69-78.

Holmes, R.J. 1994. Dendrochronology Program Library. University of Arizona, Tucson, AZ, USA.

Ionita, M.; Tallaksen, L.M.; Kingston, D.G.; Stagge, J.H.; Laaha, G.; Van Lanen, H.A.J.; Scholz, P.; Chelcea, S.M.; Haslinger, K. 2017. The European 2015 drought from a climatological perspective. Hydrology and Earth System Sciences 21: 1397-1419.

Kaennell, M.; Schweingruber, F.H. 1995. Multilingual Glossary of Dendrochronology: Terms and Definitions in English, German, French, Spanish, Italian, Portuguese and Russian. Swiss Federal Institute for Forest, Snow and Landscape Research, Berna, Switzerland.

Kretschmann, D.E.; Isebrands, J.G.; Stanosz, G.; Dramm, J.R.; Olstad, A.; Cole, D.; Samsel, J. 1999. Structural Lumber Properties of Hybrid Poplar USDA Forest Service, Washington, DC, USA. (Research Paper FPL-RP-573).

Ladányi, Z.; Blanka, V. 2015. Tree-ring width and its interrelation with environmental parameters: case study in central Hungary. Journal of Environmental Geography 8: 53-59.

Lamerre, J.; Schwarz, K.U.; Langhof, M.; von Wühlisch, G.; Greef, J.M. 2015. Productivity of poplar short rotation coppice in an alley-cropping agroforestry system. Agroforestry Systems 89: 933-942.
Liphschitz, N.; Waisel, Y. 1970. The effect of water stresses on radial growth of Populuseuphratica Oliv. La-Yaaran 20: 84-80.

Moreno-Cortés, A.; Ramos-Sánchez, J.M.; Hernández-Verdeja, T.; González-Melendi, P.; Alves, A.; Simões, R.; Carlos Rodrigues, J.; Guijarro, M.; Canellas, I.; Sixto, H.; Allona, I. 2017. Impact of RAV1-engineering on poplar biomass production: a shortrotation coppice field trial. Biotechnology for Biofuels 10: 110 .

Nechita, C. 2013. The influence of early wood and late wood to emergence of pointer years in oak trees. Journal of Horticulture, Forestry and Biotechnology 17: 41-47.

Paganová, V.; Jureková, Z.; Merganič, J. 2009. Growth of the dominant woody plants of floodplain communities in the changing hydrological and climatic conditions. Wood Research 54: 23-36.

Pereira, S.; Costa, M.; Carvalho, M.; Rodrigues, A. 2016. Potential of poplar short rotation coppice cultivation for bioenergy in Southern Portugal. Energy Conversion and Management 125: 242-253.

Przybysz, K.; Przybysz, P. 2013. Poplar wood as a raw material for the paper industry in the twenty-first century. Forestry and Wood Technology 84: 56-59.

Rinn, F. 2012. TSAP-Win: Time Series Analysis and Presentation for Dendrochronology and Related Applications. Scientific Research, Heidelberg, Germany.

Schweingruber, F.H. 1988. Tree Rings: Basics and Applications of Dendrochronology. D. Reidel, Dordrecht, Germany.

Šēnhofa, S.; Zeps, M.; Matisons, R.; Smilga, J.; Lazdiṇa, D.; Jansons, A . 2016. Effect of climatic factors on tree-ring width of Populus hybrids in Latvia. Silva Fennica 50: 1-12.

Speer, J.H. 2010. Fundamentals of Tree-Ring Research. University of Arizona Press, Tucson, AZ, USA.

Spinoni, J.; Naumann, G.; Vogt, J.V.; Barbosa, P. 2015. The biggest drought events in Europe from 1950 to 2012. Journal of Hydrology: Regional Studies 3: 509-524.

Stajić, B.; Vučković, M.; Janjatović, Ž. 2014. Preliminary dendroclimatological analysis of sessile oak (Quercus petraea (Matt.) Liebl.) in "Fruška Gora" National Park, Serbia. Baltic Forestry 21: 83-95.

Tomczyk, A.M.; Szyga-Pluta, K. 2018.Variability of thermal and precipitation conditions in the growing season in Poland in the years 1966-2015. Theoretical and Applied Climatology. DOI: 10.1007/s00704-018-2450-4

Trnka, M.; Fischer, M.; Bartošová, L.; Orság,M.; Kyncl, T.; Ceulemans, R. 2016. Potential and limitations of local tree ring records in estimating a priori the growth performance of shortrotation coppice plantations. Biomass and Bioenergy 92: 12-19.

Wigley, T.M.L.; Briffa, K.R.; Jones, P.D. 1984. On the average value of correlated time series, with applications in dendroclimatology and hydrometeorology. Journal of Climate and Applied Meteorology 23: 201-213.

Wojtan, R.; Tomusiak, R. 2014. Comparison of radial growth of common ash and black alder growing in the close neighborhood. Studia i Materiały CEPL 16: 99-104. (in Polish, with abstract in English).

Zieliński, P.; Górniak, A.; Piekarski, M.K. 2009. The effect of hydrological drought on chemical quality of water and dissolved organic carbon concentrations in lowland rivers. Polish Journal of Ecology 57: 217-227. 